УДК 82.09:821.111(73)+17.021.2

Лучицька М. $\boldsymbol{C}_{\text {, }}$ кандидат філологічних наук, старший викладач кафедри практики германських мов Кіровоградського державного педагогічного університету імені Володимира Винниченка

\title{
THE NARRATIVE OF THE IMAGINARY LIBERATION OF A PERSONALITY IN THE SHORT STORY «A BIT OF SINGING AND DANCING» BY SUSAN HILL
}

У статті проаналізовано наративні форми оповідання Сьюзен Елізабет Хілл «А Вit of Singing and Dancing» як способи викриття уявного вивільнення особистості та шляхи побудови історії життєвої трагедії людини, щчо втратила себе..

Ключові слова: наратив, форми нарачії, пермоособова нарачія, третьоособова нарація, всевідний наратор, дієгезис.

В статье проанализированы наррративные формы рассказа Сьюзен Элизабет Хилл «A Bit of Singing and Dancing» как способы раскрытия воображаемого освобождения личности и пути построения истории трагедии жизни человека, потерявшего себя.

Ключевые слова: нарратив, формы наррации, повествование от первого лица, повествование от третьего лица, всезнающий нарратор, диегезис.

The forms of narration of the short story by Susan Elizabeth Hill «A Bit of Singing and Dancing» as the means of revealing the person's imaginary liberation and the ways of the buildingup the selfless human-being's life-tragedy are analyzed in the article. By means of imaginary dialogues, attempts of self-assessment of the main character, the omniscient narrator discovers and underlines the true state of her mind and spirit.

Key Words: narrative, forms of narration, the first-person narration, the third-person narration, omniscient narrator, diegesis. 
The brightest samples of fiction, published in the XX century, reveal to the recipient lots of reasons and ways to reconsider and reopen some eternal notions, phenomena, thoughts. The prose is overwhelmed with impressive means and the means of expression, psychological analyses and portraits, which are materialized in the text via some vivid means of narrating, modifying the focal point of narration, diversifying types of narration. Narrative analyses becomes widely used in the sphere of philology. A literary work is considered as a structuralized unit, all components of which are coexisting as a whole, are helping in the process of the recipient's discovering its main idea and the author's messages.

Dealing with the XX century's prose, it's not surprising that the main subject of our analyses is the forms of narration, which help to discover the process of an imaginary liberation of a personality.

The object of the analyses is a short story, «A Bit of Singing and Dancing» [MESS 1978:194-215], by an English author, Susan Elizabeth Hill, a bright sample of the XX century's English prose, included into the short stories' collection of the same name, that received deserving attention of the literary and art circles in 1973.

The aim is to identify different types of narrating and the subjects of narration, which reveal the signs of false or - to be more precise and as it was already mentioned in the previous paragraphs of the article - imaginary liberation of a personality, a personal tragedy of an almost selfless dependent human-being.

The investigators in the field of literature have noticed the peculiar simplicity of the author's prose by its shape, according to the peculiarities of the narrative means and devices, but also they underlined tender deep lyrical mode of the literary works according to their central theme and idea [EC 2006:716-717]. We are interested in the author under consideration first of all in the role of a brilliant shortstory writer. The samples of Susan Hill's literary works, according to the observations of the investigators [EC 2006:716], are prominent due to their subtle psychological pictures, and the characters of her short stories are wretched, exhausted by the sufferings children, teenagers, women, senior citizens. 
The collections of the talented short-story writer were remarkable for receiving literary and art awards. For example, the collection, published in 1970, «The Albatross and Other Stories», was awarded with the prize of the Art Council, and the mentioned above collection of short stories, which came into the world in 1973, «A Bit of Singing and Dancing», - with the prize of L. Rice.

The narrative of the short story «A Bit of Singing and Dancing» by Susan Hill is introduced by means of a descriptive scene with the third-person narration prevailing, which reveals some basic facts about its main character. The recipient can observe a typical sea beach with its most peculiar features, but for the fact that it was February and "There was no one else on the beach so late in the afternoon» [MESS 1978:194]. This very introductive sentence (it takes the very first place in the course of narrating) underlines the main dramatic state that determines the whole life of the woman, whose life-tragedy is depicted in the sample of prose under analyses the state of loneliness. A dramatic psychological portrait of a weak-willed, lonely, not young person can be traced practically in each paragraph of her story.

The true dramatic air of loneliness is exaggerated by means of the omniscient [Prince 2003:68-69] narrator's observations - Esme's life (the life of the main character) is, or to be more precise in respect of the grammar forms prevailing, was subdued to the will, opinion, likes and dislikes of her mother. Lots of facts from her past can prove that in the form of the third-person narrator-observer's assertions. The omniscient narrator with the help of the third-person singular narration prevailing, provides an outer look at the situation - the narrator, being absent in the diegesis as an acting part of it, builds up the situations, reveals the facts in the role of its creator. That type of narrating underlines and generalizes the eternal dependence and lack of individualism in Esme's personality, actually - the absence of a true personality as it is in the depicted character.

The whole story is focused around a tragic event in the life of the main character - the loss of her mother - and all possible changes in her daily routine and self-perception after that loss. Very often the recipient can trace the word "freedom" in the text of the short-story, introduced by the omniscient narrator, although its 
connotation differs from the usual understanding of this notion. Now Esme is free physically (she is not subdued to the direct orders and commands of her mother, as it used to be earlier, for more than fifty years of their common life), but psychologically - and what is more tragic - spiritually she is still dependent on her mother's will and even on her strictly organized way of life.

The above mentioned dependence is materialized by the narrator in the form of the prevailing third-person singular remarks, which form a distinct micro-portrait of the character's psychological state after her mother's death: "She shivered then, in a moment of fear and bewilderment at her new freedom, for there was nothing she had to do, she could please herself about everything, anything, and this she could not get used to" [MESS 1978:197]. Psychological portraits drawn by the omniscient narrator are very often interwoven with the first-person narration, introducing the selfassessment of the main character and a new role of the mistress of her own life she had to endure now: "She said, but that is what I did want, to get rid of the person who bound me to her for fifty years. She spoke aloud into the bedroom, "I wanted you dead". She felt her hands trembling and held them tightly together, she thought, I am a wicked woman" [MESS 1978:199]. The author's decision to combine the omniscient narrator's observations with the first-person narration of the main character, given either in the form of the direct speech or the reported thoughts, highlights the degree of great psychological strain, caused by the uncertainty of the future for a person who lost her usual subdued and humble day-to-day way of living, as well as by the necessity to be able to make decisions and to build-up all further serious steps and changes without anybody else's help.

Being afraid of any serious changes in her usual way of life, the main character, somewhere deep in her heart, was eager to change it. The focal point of those changes is the appearance of Mr. Amos Curry, a person who gradually brings those cherished changes in Esme's reality, but which are still being measured, deep in her heart, by her mother's instructions and view points. The dialogue, which introduces this new character, appears to brighten the diegesis of the short story as another vivid proof of Esme's total dependence on her mother. Telling her correct 
address to Mr. Amos Curry, who was planning to rent a room, but accidentally mixed up the places, she remarks: "I think you have the wrong address [...] 'Oh, no, I'm sorry, we are ...' she corrected herself, 'I am, twenty-three Park Walk' ", [MESS 1978:200]. That very "we are", which unconsciously came first in her answer, proves her disability to give up thinking she is still not alone in her house.

The main character's assessment of the stranger as a personality is also given as another bright proof of her constant dependence on her mother's judgement: "She thought, he is a very clean man, very neat and spruce, he has a gold incisor tooth and he wears gloves. Her mother had always approved of men who wore gloves. 'So few do, nowadays. Gloves and hats. It is easy to pick out a gentleman,", [MESS 1978:200]. The third person narration here is given as a mixture of the omniscient narrator's story-telling and Esme's thoughts, which totally reflect her mother's image of a true gentleman. The approval of the visitor's further presence in her house is totally based on this fact.

The main character's life, alongside with her constant eagerness to think that she is free of any outer influence now ("I should be daring, I should allow myself to be constantly surprised. Each day I should be ready for some new encounter. That is how to stay young" - as her inner voice suggests) and to be free enough to challenge herself, is still permanently subdued to her mother's orders and instructions: "Now, she heard her mother talking about Mr. Curry. 'You should always take particular notice of the eyes, Esme, never trust anyone with eyes set too closely together'. She tried to see his eyes, but he was turned sideways to her. 'Or else too widely apart. That indicates idleness' " [MESS 1978:205-206]. That author's decision - to insert her mother's voice into the omniscient narrator's story-telling process - underlines the deepness of that influence, which is still acute and permanent, living within the mind and the soul, conquering the will and thoughts.

The omniscient narrator overwhelms the diegesis of the short-story under analyses with imaginary dialogues of a mother and a daughter, indicating the constant progress of that Esme's incurable trauma - whatever she does she is seeking for approval or disapproval of her role-model: "There was no doubt that her mother 
would have disapproved, and not only because he was a 'stranger off the streets'. 'He is a salesman, Esme, a doorstep pedlar, and you don't know what his employment in the summer months may turn out to be'. 'He has impeccable manners, mother, quite old-fashioned, and a most genteel way of speaking'. She remembered the gloves and the raised hat, the little bow, and also the way he had quietly and confidently done the washing-up, as though he were already living here" [MESS 1978:208]. Being invisible in the text, not existing in the diegesis as a character [Женетт 1998], the omniscient narrator is still explicit there - the author's decision is to give him a specific role: the so called inner-psychologist who constantly reveals fears, doubts, and true poor Esme's state of mind, the tragedy of a selfless and totally dependent human-being.

The true culmination of Esme's dependence upon her mother is her decision, dictated in their imaginary dialogues, to figure out what Mr. Curry's summer job really looked like. The discovery that he is just a street musician, doing a bit of singing and dancing, provokes lots of controversial thoughts and decisions in her head. She felt shame, disapproval, pity, she was even panic-stricken to some extend. The third-person singular narration, presented by the omniscient narrator, reveals the attempts to make independent decisions: "Mr. Curry was not dishonest [...] He paid the rent. He was neat and tidy, and a pleasant companion" [MESS 1978:214]. To crown it all, another imaginary dialogue arises hope for true freedom of Esme's mind and spirit: "'I told you so, Esme. What did I tell you?' 'Told me what, mother? What is it you have to say to me? Why do you not leave me alone?' Her mother was silent" [MESS 1978:214]. Being an adult, not even a young one, the main character is eager to be able to make decisions, based on her personal opinion, likes and dislikes.

Unfortunately the very final scene of the short-story is presented as another final and undisputable proof of the main character's dependence, imaginary, not real, liberation: "Esme Fanshaw said, looking at him: 'My mother used to say, Mr. Curry, 'I always like a bit of singing and dancing, some variety' It takes you out of yourself, singing and dancing' Mr. Curry gave a little bow" [MESS 1978:215]. Her choice to 
approve Mr. Curry's summer occupation is totally dependent on her mother's likes and dislikes.

In conclusion, the short-story "A Bit of Singing and Dancing» by Susan Elizabeth Hill is a bright and vivid example of the XX century's prose, full of psychological portraits, self-analyses, impressive and expressive means. The narrative of the story under analyses demonstrates the domination of the third-person narration models, presented by the omniscient narrator, interwoven with the imaginary dialogues and psychological self-assessment of the main character. Taking the role of an inner-psychologist, the narrator generalizes the revealed problem of a self-less, dependent human-being and exposes the imaginary nature of her liberation in each phrase and situation: the voice of her mother sounds not only in the numerous imaginary inner-dialogues, but also in her mind, in her will, in her choices.

\section{БІБЛІОГРАФІЯ}

Женетт 1998 - Женетт Жерар. Фигуры. В 2-х томах / Жерар Женетт. Том 2. - М. : изд-во им. Сабашниковых, 1998. - 472 с.

EC 2006 - Зарубіжні письменники. Енциклопедичний словник. У 2 т. Т. 2: Л - Я ; за ред. Н. Михальської та Б. Щавурського. - Тернопіль : Навчальна книга. Богдан, 2006. - 864 с.

MESS 1978 - Making It All Right. Modern English Short Stories. - Moscow : Progress Publishers, 1978. - 457 p.

Prince 2003 - Prince G. A Dictionary of Narratology. Revised Edition / G. Prince. - Lincoln and London: University of Nebraska Press, 2003. - 126 p. 